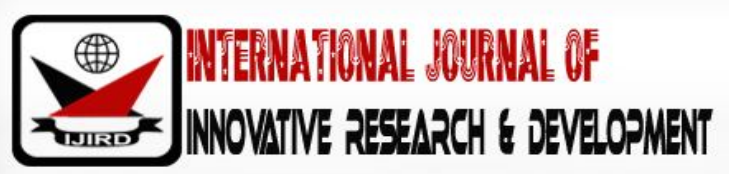

ISSN 2278 - 0211 (Online)

\section{An Evaluation of Pre-Contract Cost Planning Process for Building Projects in Tanzania}

\author{
Didas S. Lello \\ Assistant Lecturer, Department of Building Economics, Ardhi University Tanzania, Tanzania
}

\begin{abstract}
:
This research paper is about evaluation of the pre-contract cost planning process for building projects in Tanzania. Relevant literature was reviewed and analyzed by testing the views of practicing and consulting architects, engineers (both structural and services) and quantity surveyors on the pre-contract cost planning process (PCPP) for building projects against existing models/ practices/ frameworks/ mechanisms. Data collection tools were questionnaire survey and in-depth interviews. A total of 55 questionnaires were distributed of which 34 questionnaires were returned equivalent to 63.7 per cent success rate. Similarly, a total of 22 interviews were conducted.

Findings showed that the pre-contract cost planning process is done in different approach not consistent to principles. Key stages to the pre-contract cost planning role are skipped in the process. Another weakness includes lack of close cost monitoring of design variables. However, though inadequate cost planning is a leading factor towards cost overrun, other factors were also identified contributing to the problem. The study has recommended for a need to raise adherence to professional accountability, improve statutory mandates and introduce professional indemnity insurance, increase collaborative efforts between clients, consultants and related project stakeholders.
\end{abstract}

Keywords: Pre-contract, cost planning, process, quantity surveying, teamwork approach, value for money, Tanzania

\section{Introduction}

Pre-contract cost planning is one of the key functions of quantity surveying services. Before the Second World War, quantity surveying was largely used as an accountancy function. Quantities were measured from the working drawings to provide a bill of quantities (BOQ), and after completion of the works on site the final account was agreed. No attempt was made to relate these costs or to consider any cost implications of design variables or comparisons with similar schemes (Ashworth, 1999; Ashworth, 2004). Ling and Ho (2013) purported that Quantity surveying firms are generally tasked with cost and contract management duties. To achieve sustained growth and competitiveness, Frei et al (2013) cited in Ling \& Ho (2013), Oosthuizen \& Berry (2013) identified people as an important critical success factor (CSF) for quantity surveying firms. The people in these firms need to have job knowledge, job experience and task proficiency to provide service in a timely, accurate and reliable manner.

In Tanzania, the trend shows that, until recently, there were perceptions that preparation of BOQ was the main activity, while in actual fact BOQs account for $25 \%$ of the quantity surveyor's workload. This scenario was brought to attention and addressed in the paper by Mushumbusi (2010) during the 13th CPD seminar in Dodoma, 19 March, 2010 that was organized by Architects \& Quantity Surveyors Registration Board (AQRB). BOQ on the other hand is one of the key stages of cost planning process. It has also been revealed in a recent study by Ernest et al (2017) that, in developing countries, the adoption of effective cost planning practices is lacking to the extent that construction projects are often abandoned because of poor cost planning practices leading to cost overruns that are not sustainable. This study was carried out to evaluate the methods and systems adapted for cost planning practices in the Ghanaian construction industry. Such methods included; elemental cost planning, comparative cost planning, least-cost planning, functional cost planning, life cycle cost planning, unit method cost planning, cost-benefit analysis, superficial area method and cubic method.

Pre-contract cost planning is one of the core engines of project cost management, which in turn forms part of project management body of knowledge. Ling \& Ho (2013) advocate that adequate cost management ensures projects are completed within budget, which is one of the three big project outcomes (cost-time-quality). Generally, project management is the process of controlling project variables which are time, cost, quality, scope and risks (Project Management Institute, 2000; Project Management Institute, 2004; Association of Project Management, 2006; Mamiro \& Kasuwi, 2005). Results from a study by Price et al (1998) demonstrated that, a relationship exists between project cost growth and best practices associated with 
pre-project planning, project change control and team building. Elhag et al (2005) cited in Ji et al (2014) argued that only quantitative factors can be taken into consideration when estimating tender prices of projects. Since the nature of qualitative factors is difficult to measure, most qualitative factors, such as client priorities, project characteristics, and procurement methods are often ignored in the actual cost estimation process. A firm understanding of these qualitative tender costinfluencing factors could improve the competence of quantity surveyors to prepare more reliable and accurate tender estimates. This knowledge is also critical for quantity surveyors to achieve cost control at the construction stage (Ji et al, 2014).

This research is concerned with the cost planning role. It evaluates the pre-contract cost planning process in practice today specifically for building projects in Tanzania. Because of the critical importance of cost planning, it was then noted that proposals for new projects necessitated the need to have cost limits being approved, and that a "cost plan" would be a useful benchmark. This would allow the architect and even the engineer relate design more easily to the costs allowed and assist other design team members in the design decision making (Seeley,1996; Kwakye, 1997; Kamala \& Hayilakwahhi, 1997).

The essence of pre-contract cost planning is to assist designers achieve a balanced and economical design solution that is cost effective to the required quality and function and within budget. It ensures that the tender figure is as close as possible to the first estimate, or that any likely difference between the two is anticipated and within an acceptable range. It further ensures that the funds available for the project are allocated effectively and economically to the elements and subelements. Finally, aim to achieve good value at the desired level of expenditure (Ostrowski (2013) cited in Ernest et al (2017). However, most building projects have continued to be cost off-target involving cost disproportion, cost exceeding budget (cost overrun), ill-defined scope, deficiencies in the design and lack of close cost monitoring of design variables (Ramabodu \& Verster, 2010). Furthermore, Ramabodu \& Verster (2013) in their empirical analysis affirmed that the change in scope of work on site, incomplete design at the time of tender, contractual claims (extension of time with cost), lack of cost planning and monitoring of funds, and delays in costing variations and additional works were the main factors that influence the project cost and schedule overrun within the construction industry. One of the empirical studies has also noted that, construction in Africa has a history of poor project performance recorded on various types of immovable built environment assets. The net effect of cost overruns, time overruns, low productivity, accidents, building collapses, and defects is an industry that appears to be broken, when compared to the industry in other parts of the world (Emuze, 2017; Mamiro \& Kasuwi, 2005).

Literature shows that different researchers have used different approaches to classify factors affecting construction tender prices and cost overruns and summarized in a study carried out by Ji et al (2014). Table 1 therefore summarizes all the construction cost/ tender price influencing factors identified from the literature under six main categories: project characteristics, client characteristics, contractor characteristics, tendering situation, consultant and design, external factors and market conditions, and inaccuracy of cost estimating (Ji et al, 2014).

\begin{tabular}{|c|c|c|}
\hline Project Characteristics & Client Characteristics & Inaccurate Cost Estimating \\
\hline $\begin{array}{l}\text { - } \text { Buildability } \\
\text { Scale and scope of } \\
\text { - } \text { Construction } \\
\text { Construction } \\
\text { techniques } \\
\text { - } \text { Location } \\
\text { - } \text { Project duration } \\
\text { - } \text { Type of construction } \\
\text { Access to site and } \\
\text { - } \text { storage limitations } \\
\text { - } \text { Pype of structure } \\
\end{array}$ & $\begin{array}{l}\text { - } \quad \text { Financial ability of client } \\
\text { - } \quad \text { Deadlainty of project brief } \\
\text { - } \quad \text { Client requirement on quality } \\
\text { - } \quad \text { Type of client }\end{array}$ & 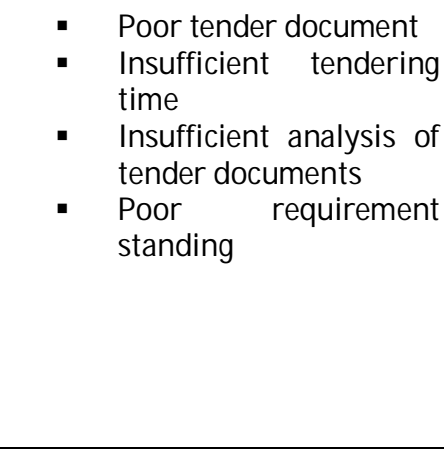 \\
\hline Contractor Characteristics & Design, Consultant and Tendering & $\begin{array}{l}\text { External Factors and Market } \\
\text { Conditions }\end{array}$ \\
\hline $\begin{array}{ll}\text { - } & \text { Experience on similar } \\
\text { - } & \text { projects } \\
\text { - } & \text { Panagement team } \\
& \text { clients } \\
\text { - } & \text { Current work load } \\
\text { - } & \text { Need for work } \\
\text { - } & \text { Planning capability }\end{array}$ & $\begin{array}{ll}\text { - } & \text { Completeness of project information } \\
\text { - } & \text { Incomplete/ incorrect design } \\
\text { - } & \text { Procurement method } \\
\text { - } & \text { Type of contract } \\
\text { - } & \text { Tendering method }\end{array}$ & $\begin{array}{l}\text { - Level of competition } \\
\text { and level of } \\
\text { - } \quad \text { Material cost } \\
\text { - } \quad \text { Labour cost } \\
\text { - } \quad \text { Number of bidders } \\
\text { - } \quad \text { Market stability } \\
\text { - } \quad \text { Interest/ inflation rate }\end{array}$ \\
\hline
\end{tabular}

Table 1: Cost/ Tender Price Influencing Factors

Source: Adopted from (Ji Et Al, 2014) 
This cost planning practice was largely being carried out in developed countries with deeper roots in the UK from 1900s. The practice also has strong roots in Australia, New Zealand, South Africa, Nigeria and Kenya. In Tanzania, quantity surveying profession was officially launched before national independence in 1947. Since then, it has been observed that, a quantity surveyor became weak partner in the design team, until recently where his position started to be realized as a key design member by assisting to develop design alternatives that meet client's requirements in terms of resource constraints (Mushumbusi, 2010). It is no use designing a building which meets the functional, dimensional and technological requirements of the brief, and is aesthetically satisfying, but which the client cannot afford.

The process of cost distribution, monitoring and control during the project design stage is generally known as cost planning. Life cycle costs are also part of the cost goal in the scope of the design-to-cost plan. Some empirical studies carried out over the last two decades, argued that cost planning should more appropriately be renamed 'value planning', although there is an emphasis on ensuring that tender sums equate with approximate estimates. The other intention is to provide a balanced design and value for money (Barton, 1985; Ramus, 1989; Seeley,1996; Rao, 1999).

Clients have recently become more exacting and cost conscious for reasons of profitability and accountability. In one of his papers over the last two decades, Mushumbusi (1997) noted that user needs (by clients or investors) started to switched on strict measures of adherence to budgets, achieved through; realistic technical feasibility studies, optimum designs, rigorous cost planning and cost monitoring, and good project planning and management. Since 1998, studies have shown a tremendous increase in construction costs. It is even more explicit in today's concern of rising prices and high inflation rates, restrictions on the use of capital coupled with high interest rates, cash flow problems, scarcity of resources, constant imbalance between requirements and capacities, legal issues, taxes and bureaucratic inefficiencies implying that cost should be accepted as a serious element in the design and that buildings should be designed and executed accordingly to suit the pockets of developers, purchasers and renters whose income earning capacity does not often keep pace with planning and architectural opinion (Kesogukewele, 1998; Mutabuzi, 2007).

Figure 1 below highlights areas of attention for cost optimization during the pre-contract cost planning. The model portrays key challenges facing the current role of the pre-contract cost planning for building projects to achieve today's fierce client's requirements.

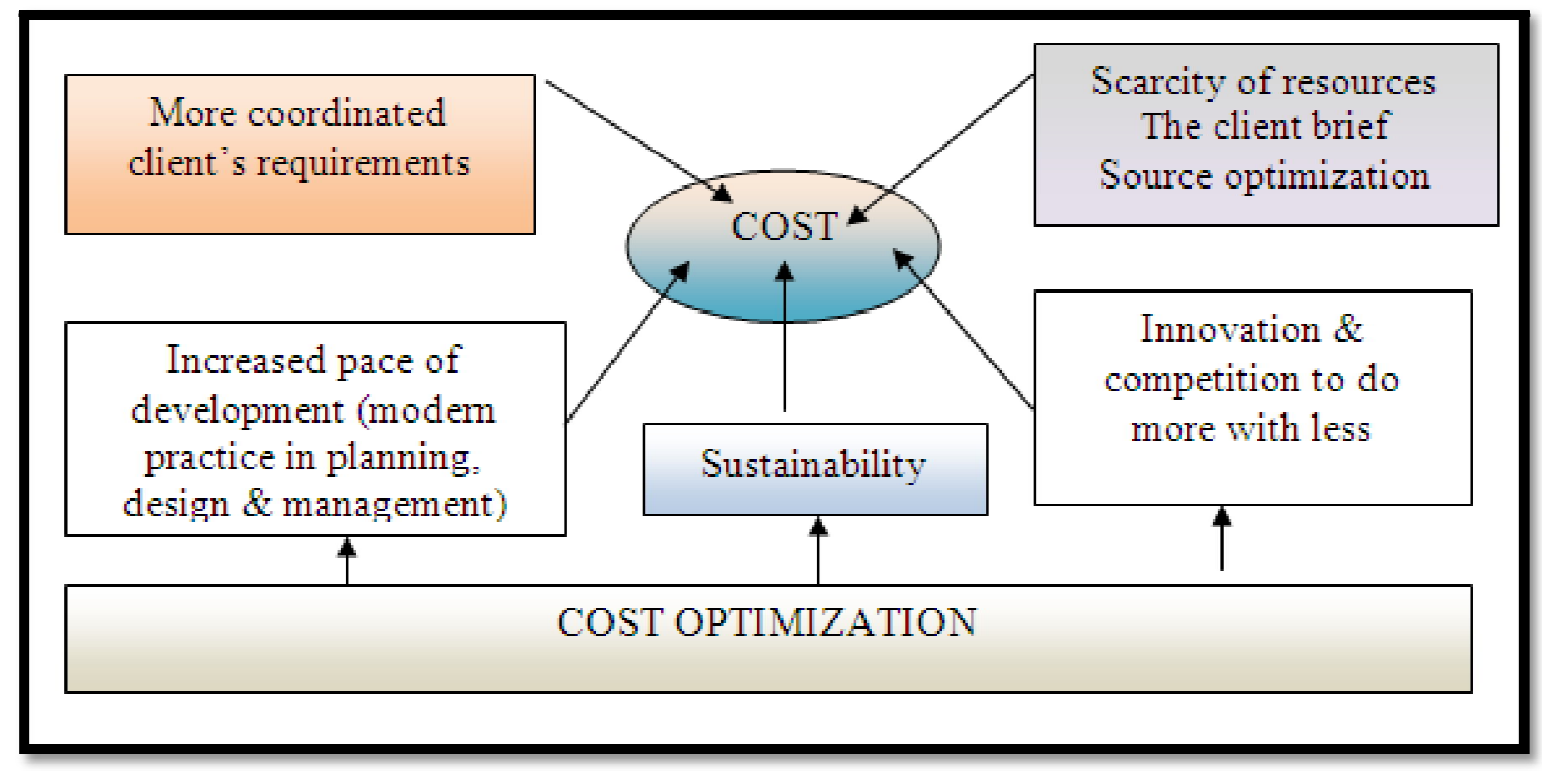

Figure 1: Triggers of Resource Optimisation (Source: Adapted from Mushumbusi, 2005)

Construction projects are now larger, with technical complexity. This is a major challenge to cost planners (especially quantity surveyors) in their role to advice clients on the probable and more realistic cost estimate early at the pre-tender stage (Ashworth \& Hogg, 2007; Potts, 1994; Ramabodu \&Verster, 2010). Again Ashworth (1999) and Ferry \& Brandon (1991) argues that ineffective cost planning in the initial stage would result into commencement of the design all over again, which is usually not possible or not cost-effective for either the client or the designer. Another worst step that could happen is that the project can be abandoned and this is satisfactory neither to the designer, who may lose the fees for supervision work, nor to the client, who has to pay for design fees.

\section{The Pre-Contract Cost Planning Process}

Kwakye (1997) has expounded the need for design evaluation as an important parameter of cost planning. As the initial budget estimate is always the one that is remembered by a client, steps must be taken to ensure that the initial figure is not exceeded (RICS Books, 2003; Ashworth \& Hogg, 2007). This is because the design of a building influences its eventual 
overall cost, necessitating the design team to evaluate the cost, quality, function, aesthetics and design before the project leaves the drawing board.

Normally the design evaluation process is composed of distinct but interrelated functions of cost planning, life-cycle costing and cost/ feasibility studies as shown in Figure 2 (Edmeades, 1973; Kwakye, 1997). Thus, in cost planning for building projects, the cost planner/ QS should be working hand in hand with the architect by visiting him or her frequently, evaluate cost aspects of his/ her drawings and those of other consultants (structural and MEP engineers) to help get drawn what the client can afford i.e. helping them to design to the cost (Tango, 2004).

As the design progresses, checks are made against design and the necessary financial adjustments are also made among the elements. Figure 2 presents a model by Kirkham (2007) that shows the conventional stages of cost planning process. It insists that after every design stage, life cycle costs of design variables must also be assessed for decision making. Similarly, post-occupancy evaluation is carried.

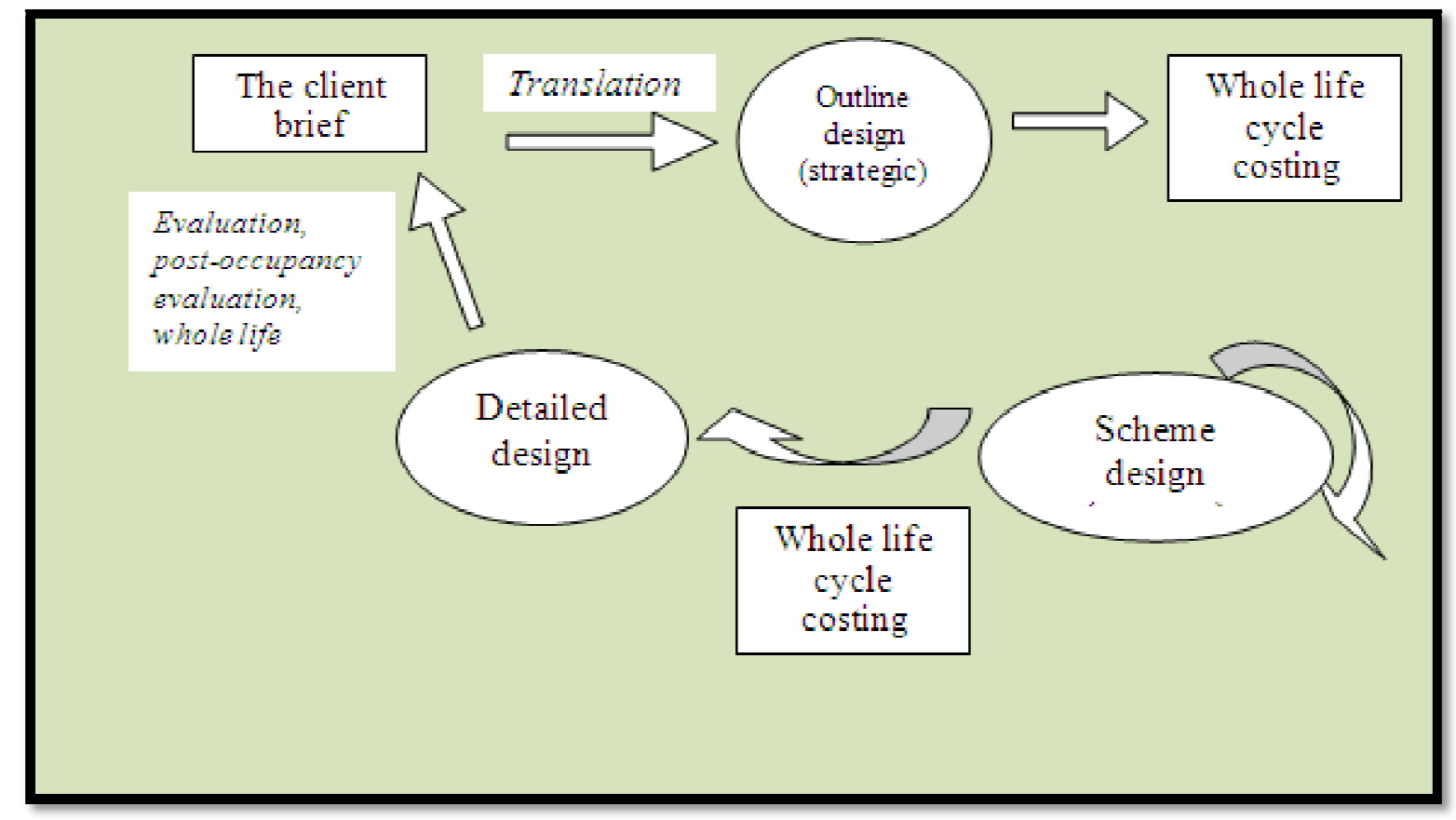

Figure 2: The Conventional Stages of the Cost Planning Process (Source: Adopted from Kirkham, 2007)

Going further, Kirkham (2014) cited in Ernest et al (2017) summarized and outlined the cost planning process in three phases, these are:

- $\quad$ Phase 1: Defining the brief and setting the budget. In disciplines out of construction project management, this is commonly referred to as scoping or framing.

- $\quad$ Phase 2: The cost planning and control of the design process. This phase is of critical importance since decisions made at design have a direct impact upon whole life performance.

- $\quad$ Phase 3: The cost control of the procurement and construction stages

RICS Books, (2003) presents a very clear and improved cost planning process as depicted in Figure 3. For each design stage, it is clearly shown how a cost planner (or QS) must fulfill his tasks. After each task he/ she must prepare deliverable reports for assisting key decisions to be made at each stage of the design process. 


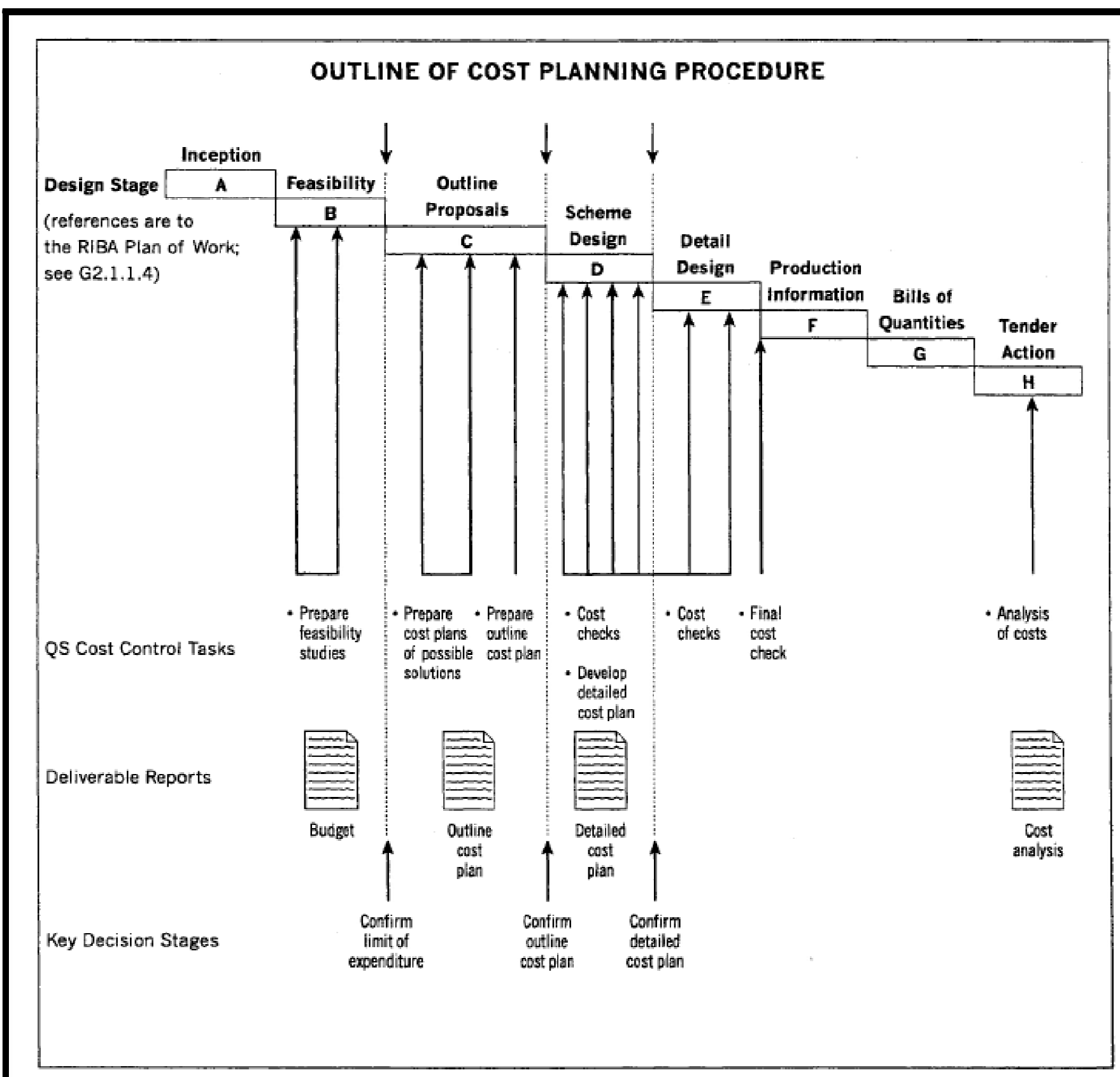

Figure 3: An Outline of Cost Planning Procedure/ Process (Source: RICS Books, 2003)

Normally in the design decision-making process, a complete system of pre-contract cost planning would comprise elemental cost plan, comparative cost plan, cost checking and life-cycle costing as summarized in Table 2 . According to Luvara (2009), cost planning process in Tanzania normally involves the following stages:

- Preliminary estimating

- Preparation of cost plan: requirements are preliminary sketch drawings, indication of materials to be used, contractual information and comparable cost analysis from previous project

- Cost checking when there is cost limit

- Tender reconciliation and

- $\quad$ Post-contract cost control

One fundamental question is that, is the pre-contract cost planning process effective? Are the above roles executed in each key stage of the cost planning process indicated in Figure 4? These roles are summarized in Table 2 below clearly emphasizing the required procedure in the pre-contract cost planning process. 


\begin{tabular}{|c|c|c|c|c|}
\hline SN & Method/ System & Function/ Meaning & $\begin{array}{l}\text { Critical Stage } \\
\text { In The Process }\end{array}$ & References \\
\hline 1 & $\begin{array}{l}\text { Elemental cost } \\
\text { planning }\end{array}$ & $\begin{array}{l}\text { The designer then proceeds to develop the } \\
\text { design within the framework (for each } \\
\text { building element) of what he or she believes to } \\
\text { be the appropriate economic approach, but not } \\
\text { exceeding the design budget the designer may } \\
\text { have to re-design any solution that has a cost } \\
\text { that does not fit in with the cost plan. }\end{array}$ & $\begin{array}{c}\text { At feasibility } \\
\text { and outline } \\
\text { stages [refer } \\
\text { Figure 4] }\end{array}$ & $\begin{array}{l}\text { Seeley, 1996; } \\
\text { Kwakye, 1997; } \\
\text { Ashworth \& Hogg, } \\
\text { 2007). According } \\
\text { to Kwakye (1997), }\end{array}$ \\
\hline 2 & $\begin{array}{l}\text { Comparative cost } \\
\text { planning }\end{array}$ & $\begin{array}{l}\text { This is somehow similar to elemental cost } \\
\text { planning, though however, it does not seek to } \\
\text { enforce rigid cost limits for the design } \\
\text { particular elements. It aims more at } \\
\text { maintaining the flexibility of choice of a } \\
\text { combination of possible design solutions by } \\
\text { comparing alternative possibilities within the } \\
\text { total sum allocated to an element. }\end{array}$ & $\begin{array}{l}\text { At feasibility } \\
\text { and outline } \\
\text { stages [refer } \\
\text { Figure 4] }\end{array}$ & $\begin{array}{l}\text { Seeley,1996; } \\
\text { Kwakye, 1997; } \\
\text { Ashworth \& Hogg, } \\
\text { 2007; Ernest et al, } \\
2017\end{array}$ \\
\hline 3 & $\begin{array}{l}\text { Cost in use or life } \\
\text { cycle costing }\end{array}$ & $\begin{array}{l}\text { User cost in today's economic era, is one of the } \\
\text { key components of construction costs that } \\
\text { deserves adequate consideration. Thus, in } \\
\text { addition to capital costs, the cost planner must } \\
\text { consider operating and maintenance costs. The } \\
\text { primary use of whole life costing in } \\
\text { construction is in the evaluation of alternative } \\
\text { solutions to specific design problems. The } \\
\text { whole life cycle cost plan is a combination of } \\
\text { initial, maintenance, replacement, energy, } \\
\text { cleaning and management costs. Sometimes } \\
\text { known as 'whole cost accounting' or 'total cost } \\
\text { of ownership. }\end{array}$ & $\begin{array}{l}\text { At feasibility, } \\
\text { outline \& } \\
\text { scheme design } \\
\text { stages [refer } \\
\text { Figure 4] }\end{array}$ & $\begin{array}{c}\text { Seeley,1996; } \\
\text { Kwakye, 1997; } \\
\text { Ashworth \& Hogg, } \\
\text { 2007; Ernest et al, } \\
2017\end{array}$ \\
\hline 4 & Cost checking & $\begin{array}{l}\text { The primary role of a cost planner/ quantity } \\
\text { surveyor is that of project appraisal and design } \\
\text { development with respect to budget limits } \\
\text { During the cost-checking process, if the cost of } \\
\text { an element differs from the cost plan, it may be } \\
\text { necessary to adjust the cost and other } \\
\text { elements that make a balance or utilize } \\
\text { reserves set aside in the cost plan. However, if } \\
\text { it proves impossible to keep within the set } \\
\text { target, the cost planner must report this to the } \\
\text { designer who may consider a different design } \\
\text { solution or accept the increased cost of the } \\
\text { element or the project as a whole. }\end{array}$ & $\begin{array}{l}\text { At scheme } \\
\text { design \& } \\
\text { detailed design } \\
\text { stages [refer } \\
\text { Figure 4] }\end{array}$ & $\begin{array}{c}\text { Mushumbusi, } \\
\text { 2010; RICS Books, } \\
2003\end{array}$ \\
\hline 5 & $\begin{array}{c}\text { Elemental cost } \\
\text { studies or } \\
\text { feasibility studies }\end{array}$ & $\begin{array}{l}\text { These are normally undertaken during the } \\
\text { earliest stages of the project to assist selection } \\
\text { of an optimum design solution. The aim for } \\
\text { this analysis is to determine how these costs } \\
\text { correctly reflect a given situation or relate the } \\
\text { cost of an element to its function in a } \\
\text { construction project. Similarly, the architect } \\
\text { will require an overall costing device that will } \\
\text { enable him to set a design target i.e. client's } \\
\text { capital ceiling. }\end{array}$ & $\begin{array}{c}\text { At feasibility \& } \\
\text { outline design } \\
\text { stages [refer } \\
\text { Figure 4] }\end{array}$ & $\begin{array}{c}\text { Seeley,1996; } \\
\text { Kwakye, 1997; } \\
\text { Ashworth \& Hogg, } \\
\text { 2007; Ernest et al, } \\
\text { 2017; Edmeades, } \\
\text { 1973; }\end{array}$ \\
\hline 6 & Least-cost & $\begin{array}{l}\text { It is relatively new technique that is based on } \\
\text { cost-benefit analysis and used by economists } \\
\text { for making rational decisions about } \\
\text { investments in transportation and other urban } \\
\text { Infrastructure projects including other } \\
\text { construction projects. }\end{array}$ & $\begin{array}{l}\text { At inception \& } \\
\text { feasibility } \\
\text { stages [refer } \\
\text { Figure 4] }\end{array}$ & Ernest et al, 2017 \\
\hline
\end{tabular}




\begin{tabular}{|c|c|c|c|c|}
\hline SN & Method/ System & Function/ Meaning & $\begin{array}{l}\text { Critical Stage } \\
\text { In The Process }\end{array}$ & References \\
\hline 7 & Functional & $\begin{array}{l}\text { It is based on monetary rate or amount applied } \\
\text { to a unit commensurate with the function of } \\
\text { the building. }\end{array}$ & $\begin{array}{l}\text { At inception \& } \\
\text { feasibility } \\
\text { stages [refer } \\
\text { Figure 4] }\end{array}$ & Ernest et al, 2017 \\
\hline 8 & Unit cost & $\begin{array}{l}\text { Unit cost method involves the use of a single } \\
\text { functional unit that serves as a multiplier. }\end{array}$ & $\begin{array}{l}\text { At inception \& } \\
\text { feasibility } \\
\text { stages [refer } \\
\text { Figure 4] } \\
\end{array}$ & Ernest et al, 2017 \\
\hline 9 & $\begin{array}{l}\text { Cost-benefit } \\
\text { analysis }\end{array}$ & $\begin{array}{l}\text { Cost-benefit analysis is used to evaluate those } \\
\text { aspects that have a clear money value, both of } \\
\text { a capital and recurrent nature, but intangibles } \\
\text { are merely assessed and shown separately. }\end{array}$ & $\begin{array}{l}\text { At inception \& } \\
\text { feasibility } \\
\text { stages [refer } \\
\text { Figure 4] }\end{array}$ & $\begin{array}{l}\text { Ernest et al, 2017; } \\
\text { State Government } \\
\text { of Victoria, } \\
\text { Australia, 2010. }\end{array}$ \\
\hline 10 & Superficial area & $\begin{array}{c}\text { The superficial area method, also known as the } \\
\text { floor area method, is a single price rate } \\
\text { method in which the total floor area is } \\
\text { calculated. }\end{array}$ & $\begin{array}{l}\text { At inception \& } \\
\text { feasibility } \\
\text { stages [refer } \\
\text { Figure 4] }\end{array}$ & Ernest et al, 2017 \\
\hline 11 & Cubic & $\begin{array}{c}\text { It is based on cubic volume of a building is } \\
\text { obtained by multiplying the length, width and } \\
\text { height (external dimensions) of each part of } \\
\text { the building. A single cost rate applied to the } \\
\text { internal volume of a building. }\end{array}$ & $\begin{array}{l}\text { At inception \& } \\
\text { feasibility } \\
\text { stages [refer } \\
\text { Figure 4] }\end{array}$ & Ernest et al, 2017 \\
\hline 12 & $\begin{array}{l}\text { Final cost plan } \\
\text { [techniques: } \\
\text { approximate } \\
\text { quantities \& build } \\
\text { up all-in rates] }\end{array}$ & $\begin{array}{l}\text { This is normally done after the cost planner } \\
\text { has carried out all the cost checks and has } \\
\text { affected all the necessary financial } \\
\text { adjustments; it is then time to prepare the final } \\
\text { cost plan. It is accompanied by the agreed } \\
\text { specification on which the cost plan was based. }\end{array}$ & $\begin{array}{l}\text { At detailed } \\
\text { design \& tender } \\
\text { action stages } \\
\text { [refer Figure 4] }\end{array}$ & $\begin{array}{c}\text { Seeley,1996; } \\
\text { Kwakye, 1997; }\end{array}$ \\
\hline
\end{tabular}

Table 2: System of Cost Planning

Source: Author ' Construct

\section{Methodology}

\subsection{Research Design}

The research design adopted in this study is a hybrid approach employing descriptive design which is quantitatively analyzed. It mainly aims at expressing the state of affairs as it exists (Mugenda \&Mugenda, 1999; Kothari, 2004, Yin, 2011).

\subsection{Sampling Design}

Probability sampling was used to get respondents from local consulting architects, engineers and quantity surveyors. Thus, samples were systematically selected from every "ith item" on the list for each category as summarized in Table 3. On the other hand, respondents from foreign consultants were deliberately (purposive sampling) selected using non-probability sampling because they are few (population) and information-rich as depicted in Tables $3 \& 4$.

\subsection{Population for This Study}

Table 3 shows the population for this study. The current list of respondents was obtained from respective professional bodies i.e. from Architects and Quantity Surveyors' Registration Board (AQRB) and Engineers' Registration Board (ERB) for Dar es Salaam based architects \& quantity surveyors and engineers respectively. The researcher has categorized them into local and foreign consultants each forming 338 and 18 subjects respectively giving a total of 356 consultants.

\begin{tabular}{|c|c|c|c|c|c|c|}
\hline & Firm & $\begin{array}{c}\text { Quantity } \\
\text { Surveyors }\end{array}$ & Architects & $\begin{array}{c}\text { Structural } \\
\text { Engineers }\end{array}$ & MEP Engineers & Total \\
\hline \multirow{3}{*}{ Population } & Local & 81 & 156 & 75 & 26 & 338 \\
\cline { 2 - 7 } & Foreign & 1 & 5 & 5 & 7 & 18 \\
\cline { 2 - 7 } & Total & 82 & 161 & 80 & 33 & $\mathbf{3 5 6}$ \\
\hline
\end{tabular}

Table 3: Population for Dar es Salaam Based Firms Source: AQRB Directory, 2016 and ERB Directory, 2016 


\subsection{Sample Size for This Study}

Since the population in this study is finite, the required sample for each unit/ category of analysis was obtained using the following formula and results are summarized in Table 4 below (Kothari, 2004):

$$
n=\frac{z^{2} \cdot \sigma^{2} \cdot N}{e^{2}(N-1)+z^{2} \cdot \sigma^{2}}
$$

Where: ' $n$ ' is sample size, ' $\mathrm{N}$ ' is size of population, 'e' is acceptable error (the precision (3)), ' $\sigma$ ' is standard deviation of population (5) and ' $z$ ' is standard variate (1.96) at given confidence level (95\%).

\begin{tabular}{|c|c|c|c|c|c|c|}
\hline & Firm & $\begin{array}{c}\text { Quantity } \\
\text { Surveyors }\end{array}$ & Architects & $\begin{array}{c}\text { Structural } \\
\text { Engineers }\end{array}$ & $\begin{array}{c}\text { Services } \\
\text { Engineers }\end{array}$ & Total \\
\hline Final & Local & 10 & 10 & 9 & 8 & 37 \\
\cline { 2 - 7 } Sample Size & Foreign & 1 & 3 & 3 & 4 & 18 \\
\cline { 2 - 7 } & Total & 11 & 13 & 12 & 12 & 55 \\
\hline
\end{tabular}

Table 4: Sample Size for Dar es Salaam Based Firms

\subsection{Data Collection Methods}

In conducting this research, the author has based mostly on three major approaches; questionnaire survey administered to senior consultants, while personal in-depth interviews were administered to managing directors (owners) of consulting firms and literature review to supplement primary data with secondary data. Thus, Table 4 shows that a total of 55 subjects (samples) were finally obtained from the population of 356 subjects. The sample size is enough for this study and a total of 55 questionnaires were administered to this sample as shown in Table 5, indicating success rate of $63.7 \%$.

\begin{tabular}{|c|c|c|c|c|c|c|}
\hline & Firm & $\begin{array}{c}\text { Quantity } \\
\text { Surveyors }\end{array}$ & Architects & $\begin{array}{c}\text { Structural } \\
\text { Engineers }\end{array}$ & $\begin{array}{c}\text { Services [MEP] } \\
\text { Engineers }\end{array}$ & Total \\
\hline \multirow{3}{*}{ Returned } & Local & 9 & 10 & 7 & 4 & \\
\cline { 2 - 7 } & Foreign & 1 & 1 & 1 & 1 & \\
\cline { 2 - 7 } & Subtotal & 10 & 11 & 8 & 5 & 34 \\
\hline \multirow{2}{*}{ Success } & Local & 90.0 & 100.1 & 77.8 & 50.0 & \\
\cline { 2 - 7 } & Foreign & 100.0 & 33.3 & 33.3 & 25.0 & \\
\cline { 2 - 7 } & Average & 95.0 & 66.7 & 55.6 & 37.5 & $63.7 \%$ \\
\hline
\end{tabular}

Table 5: Achieved Questionnaire Responses

Also, Table 6 shows achieved interviews which were intentional administered to practicing managing directors/ partners (owners) including one foreign consultant for each category that were recorded with the help of a digital voice recorder.

\begin{tabular}{|c|c|c|c|c|}
\hline SN & Respondents & \multicolumn{3}{|c|}{ Number of Interviews } \\
\cline { 3 - 5 } & & Targeted & Interviewed & Percentage Of Success (\%) \\
\hline 01 & Quantity Surveyors & 10 & 8 & 80.0 \\
\hline 02 & Architects & 10 & 6 & 60.0 \\
\hline 03 & $\begin{array}{c}\text { Structural } \\
\text { Engineers }\end{array}$ & 8 & 5 & 62.5 \\
\hline 04 & Mep Engineers & 5 & 3 & 60.0 \\
\hline & Total & 33 & 22 & Average 65.6 \\
\hline
\end{tabular}

Table: 6: Achieved Number of Interviewees

\subsection{Data Processing, Analysis and Presentation of Findings}

Data processing technique was done using statistical software packages (SSP) i.e. SPSS for Windows version 16.0 software. Descriptive statistics were calculated for each variable. SPSS was used to generate cross tabulations showing cell frequencies to summarize response statements.

Both qualitative and quantitative methods of analysis were used for this study. Qualitative analysis was used thematically to analyse all views, opinions and comments responded from open-ended questions. This includes all other opinions from in-depth interviews in corresponding to the way cost planning process is carried out in practice today. 


\section{Results, Findings and Discussion}

\subsection{Pre-Contract Cost Planning Process and Approach Commonly Practised in Tanzania}

Basically, key stages involved in the process are inception, feasibility, outline proposal, scheme design, detailed design, BOQ production \& documentation and lastly tender action as depicted in Table 8. This is the core area of discussion that is centred to achieve answering the first specific objective of this study.

To properly get views on the way the process is carried in practice today, a question was asked to respond to options listed in Table 7. However, in-depth interviews were conducted to achieve further views and discussions. Findings from architects, engineers and quantity surveyors have suggested that cost planning is done but in different approach to principles, which was replied by 13 out of 34 respondents. This is a high response rate ranking 'first' meaning the most deficient feature of the pre-contract cost planning process. The principle requires that at each key stage of the cost planning process as the design develops, cost check and reconciliation must be done. Interviews conducted suggest that this malpractice is due to lack of professional accountability.

Similarly, 7 out of 34 respondents argued that only estimates are prepared based on the outline proposals and no follow up until final detail design. This was the second ranked score. This means that during scheme and detailed design no cost checks are done to ensure that the budget does not exceed limit. One long serving quantity surveyor replied in an interview that ".....cost planning is never done...what is needed is just BOQ......and put the QS under pressure......."

A small proportion of respondents ( 5 out of 34) have argued that cost planning is done properly, ranking ' 3.5 '. This scenario influenced the researcher to query out this trend. Thus, during the interview, the respondents said that this is due to the fact that some clients especially private investors who are cost conscious do demand a thorough cost plan. These clients are concerned about capital invested and would like to have their money borrowed wisely spent in the projects and would absolutely not entertain any cost overruns and unnecessary variations. However, the same proportion of respondents sharing the rank shows that pre-contract cost planning process is rarely done properly. On the other hand, 4 out of 34 respondents argued that cost planning is not done at all, a score that ranked 5.

\begin{tabular}{|c|c|c|c|c|c|}
\hline \multicolumn{2}{|c|}{ Views } & Frequency & Percent & $\begin{array}{c}\text { Cumulative } \\
\text { Percent }\end{array}$ & Rank \\
\hline Valid & Done properly & 5 & 14.7 & 14.7 & 3.5 \\
\hline & Rarely done & 5 & 14.7 & 29.4 & 3.5 \\
\hline & $\begin{array}{c}\text { Done, but different approach } \\
\text { to principles }\end{array}$ & 13 & 38.2 & 67.6 & 1 \\
\hline & Not done & 4 & 11.8 & 79.4 & 5 \\
\hline & $\begin{array}{c}\text { Only estimates prepared, no } \\
\text { follow up }\end{array}$ & 7 & 20.6 & 100.0 & 2 \\
\hline & Total & 34 & 100.0 & & \\
\hline
\end{tabular}

Table 7: Views on the Way Cost Planning Process Is Carried Out in Practice Today

As noted earlier in Section 2, the most important decisions regarding the quality of a completed facility are made during the design and planning stages rather than during the construction. Thus, it is obvious according to these findings projects are likely to suffer cost irregularities if the cost planning process continues to be practised the way it is done today. Table 8 is a summary of findings on each stage of the pre-contract cost planning process. It gives situational analysis of what is happening in practice today.

\begin{tabular}{|c|c|c|}
\hline Key Stage & $\begin{array}{c}\text { Critical } \\
\text { Stage }\end{array}$ & Findings \\
\hline Inception & & $\begin{array}{c}\text { Client approaches a consultant and in Tanzania the traditional approach is; first } \\
\text { engaging the architect leaving out other consultants. This is mostly practised by } \\
\text { private and individual clients/ investors irrespective of the magnitude of the } \\
\text { project. However, most public projects are procured by first employing all } \\
\text { consultants (select on teaming up basis) as per existing public procurement } \\
\text { regulations. Similarly, few cost-conscious clients do employ all consultants right } \\
\text { from the inception stage. }\end{array}$ \\
\hline Feasibility & $\sqrt{ }$ & $\begin{array}{c}\text { This is the critical stage that gives direction as to whether or not the project is } \\
\text { feasible. The aim is to ensure that the client's requirements can be reasonably } \\
\text { accommodated within the finance that is available for the project. Interviews } \\
\text { show that success at this stage depends on the nature of client. For example, } \\
\text { public clients would wait for designers to complete designs, put up the cost, and } \\
\text { then request for funds (budget) from the } \\
\text { central government. For private clients and donor funded projects there is } \\
\text { flexibility of design since the budget ceiling is always pre-determined. }\end{array}$ \\
\hline
\end{tabular}




\begin{tabular}{|c|c|c|}
\hline Key Stage & $\begin{array}{c}\text { Critical } \\
\text { Stage }\end{array}$ & Findings \\
\hline Outline proposals & $\sqrt{ }$ & $\begin{array}{c}\text { The aim here is to prepare cost plans of possible solutions to clients and other } \\
\text { stakeholders to approve. It has been observed from in-depth interviews that there } \\
\text { is no enough time to prepare alternative design solutions. Thus, cost plan is based } \\
\text { on one design. }\end{array}$ \\
\hline Scheme design & $\sqrt{ }$ & $\begin{array}{l}\text { At this stage, the aim is to cost check design variables against the cost plan in } \\
\text { order to develop a detailed cost plan. Again, according to interviews relatively few } \\
\text { cost checks are done and normally depend on nature of the project and/ or type of } \\
\text { client. }\end{array}$ \\
\hline Detailed design & $\sqrt{ }$ & $\begin{array}{l}\text { Again, cost checks are done to re-affirm the cost plan. However here is where } \\
\text { most problems have been observed where final cost estimate deviates to a large } \\
\text { extent from the plan at outline proposal. According to views from quantity } \\
\text { surveyors most designs are incomplete and so the final cost estimate is not } \\
\text { realistic. Mamiro and Kasuwi (2005) in their study revealed that } 92 \text { percent of all } \\
\text { audited projects had design deficiencies. This prompts variations during the } \\
\text { construction stage. }\end{array}$ \\
\hline $\begin{array}{c}\text { BOQ \& tender } \\
\text { documentation }\end{array}$ & & $\begin{array}{l}\text { From above it can be deduced that BOQs are not produced up to the required } \\
\text { level. Some have a significant scale of provisional and contingency sums since the } \\
\text { QS cannot establish thorough quantities based on poor and incomplete designs. } \\
\text { The accuracy would only depend on the experience of the quantity surveyor. }\end{array}$ \\
\hline Tender action & & $\begin{array}{c}\text { Expectations of high level of discrepancy between the estimate and the winning } \\
\text { bid are high. Table } 10 \text { clearly shows that about } 70 \text { per cent of winning bids exceeds } \\
\text { the estimate by a range of } 6 \text { to } 10 \text { percent. Nevertheless, some bidders tender } \\
\text { below estimate. }\end{array}$ \\
\hline
\end{tabular}

Table 8: Findings and/ Or Observations on Each Key Stage of Cost Planning Process

In summary, cost planning is done in a way that deviates from required principles. Certain key stages are skipped. Now do the approaches enhance pre-contract cost planning performance? The answer is that the current modality and practice do not substantiate the process to allow one reap its intended healthy benefits.

\subsection{What Could Be the Reasons for the Observed Trend above (Section 4.1)?}

One could think cost planning does not enhance value for money or rather clients do not need it. This was one of questions that the researcher asked to find out what could be the reasons if cost planning is not done. One interviewee argued "... insensitivity of some of the consultants is one of the hindrances ......". In fact, out of several interviews for practicing quantity surveyors it has been revealed that, architects and engineers cannot actualize the essence of cost planning, and the way it is supposed to be approached. Consultants must make sure (if design and costing are carried out well) cost limit is not exceeded, with minimal cost overrun and very minimal possible variations. The situation for Tanzania consulting practice is that some projects end up with variations (Mamiro and Kasuwi, 2005). Certainly, variations are inevitable but this does not guarantee unnecessary variations which always have cost implications. The extent should be reasonable. Interviews from quantity surveyors have suggested that variations may even start from 'day one' on site. One quantity surveyor responded in an interview "....it is obvious to find designing continues in the post-contract phase...."

In another observation, it was noted that cost estimates from service engineers are rarely reviewed by quantity surveyors. There are three facts worth noting here. First, last minute rushing to compile the final cost estimate, second, MEP knowledge and skills possessed by the quantity surveyor, and third experience of the quantity surveyor. It is considered that checks and balance among the project team members and the stakeholders' interventions are key success factors towards precost planning process.

As noted above incomplete designs imply possibility of unrealistic cost estimate since cost information is based on guesswork. One interviewee replied ".... you can find that drawings are not designed to the required control levels in order to measure the extent of cut or fill.... designers assume the land is level...... What picture does this bring forth?.... insensitivity of some design members and lack of accountability".

A study by Samizi (2008) indicates that cost estimation for building projects in Tanzania is normally performed at preliminary stage and after design stage only. This conforms to findings of this study indicating that very few cost checks are performed during the scheme design with a response rate of 64 percent. Another respondent said "in fact it is done very rudely. It is more or less a preliminary estimate." Another interesting observation as was noted by one interviewee is that, "some drawings require to be approved on site...where you may find an item in BOQ states '.... details to architect and/or engineer's design....'. BOQs contain a lot of provisional sums....and one cannot control cost for such a project." 


\subsection{Design Evaluation Process}

Views from the consulting team suggest that the design evaluation is done but not effective. It was observed that design and technical meetings have not been effective, weakening cost checks. Key and critical cost control stages were skipped in the process.

The usual practice suggests that designers may come up with several alternatives each valued with different cost implications to be tabled before clients. This has been rarely practiced; hopefully there could be certain reasons. Tanzanian designers have failed to bring in with design alternatives for quantity surveyors/ cost planners to cost. One interviewee said "most designers bring in concrete designs only......very rare considerations for other alternative types of designs are done. Steel or timber construction for example could be more economical with acceptable value to the client."

\subsection{Is Cost Overrun a Result of Inadequate Cost Planning Process?}

In determining whether or not this is true, several interviews were conducted to assess the reality of this phenomenon. It was noted that though this is one of the leading contributing factors, other factors have been found to have influenced cost performance in one way or another. These include client's change of mind during implementation, design errors and price fluctuations. From the findings and analysis, it is clear that inadequate cost planning process highly weakens the process of monitoring cost of design variables. If design variables are not assessed in terms of cost implication it is obvious that cost overrun is inevitable. Each stage of cost planning process has a great contribution towards cost management of the design which is a core motive of cost planning. One respondent replied that "external works for instance are sometimes not in original scope, clients therefore would re-engage the designer for such works." It has therefore been observed that there are other of reasons for cost overruns on building projects that may be quite legitimate and not necessarily an indication of poor governance of the procurement process (CoST, 2010).

In an attempt to find out whether or not consultants (architects, engineers \& quantity surveyors) have ever experience cost overrun in the past, results from survey questionnaire have suggested that most projects have overrun initial costs. A YES or 'NO' response question was set up. Results in Table 9 indicate that 27 out 33 respondents who supervised building projects have experienced cost overrun while a small proportion of only 6 out of 33 respondents were able to control costs.

\begin{tabular}{|c|c|c|c|c|c|}
\hline \multicolumn{2}{|c|}{} & Frequency & Percent & Valid Percent & Cumulative Percent \\
\hline Valid & Yes & 27 & 79.4 & 81.8 & 81.8 \\
\hline & No & 6 & 17.6 & 18.2 & 100.0 \\
\hline & Sub-Total & 33 & 97.1 & 100.0 & \\
\hline Missing & System & 1 & 2.9 & & \\
\hline & Total & 34 & 100.0 & & \\
\hline
\end{tabular}

Table 9: Experience of Cost Overrun in Building Projects

Source: Author, 2013

A pilot audit conducted by CoST Tanzania between May, 2008 and September, 2010, whereby in one area of project performance that analyzed two indicators i.e. time and cost, it was found that for sampled projects, there was an average time overrun of over $100 \%$ while the average cost overrun was $30 \%$. However, these average figures disguise variations, with little or no increase on some projects and very significant increases on others. Cost overrun would depend on type and nature of project.

\subsection{Level of Discrepancy between the Estimate (Confidential) and the Winning Bid}

One advantage of effective pre-contract cost planning process is that the tender sum is more likely to equate with the approximate estimate (Ashworth, 1999). This may be possible only when information from bid documents and BOQs is accurate to enable the contractor tender competitive price. Table 10 shows indicative extent of discrepancy between the estimate (confidential) and the winning bid as replied by respondents for projects they supervised.

\begin{tabular}{|c|c|c|c|c|}
\hline \multicolumn{2}{|c|}{ Discrepancy } & Frequency & Percent & Cumulative Percent \\
\hline Valid & $0-5 \%$ & 4 & 11.8 & 11.8 \\
\hline & $6-10 \%$ & 24 & 70.6 & 82.4 \\
\hline & $11-20 \%$ & 2 & 5.9 & 88.2 \\
\hline & $21-40 \%$ & 1 & 2.9 & 91.2 \\
\hline & Over $40 \%$. & 1 & 2.9 & 94.1 \\
\hline & Below estimate & 2 & 5.9 & 100.0 \\
\hline & Total & 34 & 100.0 & \\
\hline
\end{tabular}

Table 10: Level of Discrepancy between the Estimate (Confidential) and the Winning Bid 
It could be seen that 24 out 34 respondents experienced a discrepancy of between 6 and 10 percent between the confidential estimate and the winning bid. Only 4 out of 34 respondents had experienced a discrepancy of between 0 and 5 percent above the estimate. Few cases were also noted where the winning bid had exceeded the estimate to over 11 percent. Other cases included those where winning bids were below the estimate as replied by 2 out 34 respondents.

\subsection{The Need for Pre-Contract Cost Planning for Building Projects in Tanzania}

Interviewees have shown a great concern for the need for cost planning for building projects. 20 out of 33 respondents replied '..... it is extremely needed...' ranking the highest score as depicted in Table 11 below. This is because cost control is well kept under scrutiny from the pre-contract cost planning exercise. A frequency shown as 'missing system' means one respondent did not attempt this question However, 1 out of 33 respondents replied '...it is not needed'.

\begin{tabular}{|c|c|c|c|c|c|c|}
\hline \multicolumn{2}{|c|}{} & Frequency & Percent & $\begin{array}{c}\text { Valid } \\
\text { Percent }\end{array}$ & $\begin{array}{c}\text { Cumulative } \\
\text { Percent }\end{array}$ & Rank \\
\hline Valid & Not Needed & 1 & 2.9 & 3.0 & 3.0 & 5 \\
\hline & Somewhat Needed & 2 & 5.9 & 6.1 & 9.1 & 4 \\
\hline & More Needed & 3 & 8.8 & 9.1 & 18.2 & 3 \\
\hline & Greatly Needed & 7 & 20.6 & 21.2 & 39.4 & 2 \\
\hline & Extremely Needed & 20 & 58.8 & 60.6 & 100.0 & 1 \\
\hline & Sub-Total & 33 & 97.1 & 100.0 & & \\
\hline Missing & System & 1 & 2.9 & & & \\
\hline & Total & 34 & 100.0 & & & \\
\hline
\end{tabular}

Table 11: The Need for Cost Planning in Tanzania's Construction Industry

The above information therefore shows a major proportion of respondents ( 60.6 percent) suggest that there is a need to start applying new attitudes and strategies to emphasize on the essence of well-defined cost planning process. One of the respondents asserted that "..... new challenges and constraints will keep flowing...we need to adopt new ways and strategies of doing cost planning".

In a study carried out by Luvara (2009), on value management for building projects, it was also revealed that cost planning approach is one of the methods to enhance value for money of a project. Furthermore, Ramabodu and Verster (2010) cited in Ernest et al (2017) contended that cost planning practices ensure that in the early stages of a project, the developer will know what the anticipated final cost of the development will be. For example, land, legal issues, demolitions, buildings, professionals, furniture, connections, tax, financing and management among others, are some of the costs that may be anticipated.

\section{Conclusion}

The following conclusions can be drawn from this study. The study has revealed out that the current practice of cost planning is done differently to outline principles. Stages essential for the process are skipped. It was also observed that estimates are prepared but no follow up in monitoring cost of design variables in order to identify their cost implications. Among the reasons why cost planning is done but in different approach not consistent to principles include; lack of professional accountability and ethics, inadequate time for design evaluation, low fees and political elements and related malpractices affecting the pre-contract cost planning process.

Essentially, a realization of effective and sustainable pre-contract cost planning process is required among project design team members and other project stakeholders. Interventions to the observed irregularities towards effective precontract cost planning process have been proposed as discussed briefly in section 6 below. In sum, further analysis on critical barriers to the effective pre-contract planning process need to be explored in order to mitigate the aforesaid weaknesses.

\section{Recommendations}

Basing on the findings and conclusions drawn, the researcher has outlined the following recommendations:

- Increase in professional accountability. Professional consultants are argued to raise awareness and have a sense of feeling professionally indebted while carrying out their services.

- Establishment of regulatory mandates and audits. This goes parallel with improved policies. Clients must have a freedom or mandate of putting a consultant into task by demanding professional indemnity insurance.

- CPD emphasis to consulting professionals (architects, engineers, quantity surveyors and project managers) could help sensitize effective cost planning process. Also, college training to construction graduates on the essence of cost planning should be over-emphasized.

- Adapt a knowledgebase technology such as 'ProjectWinner' and other computer construction software in approaching the pre-contract cost planning exercise whose greatest advantage is to assist on speed and accurate cost estimate. This 
may be accompanied by increase of research on cost analyses. Building Information Modelling (BIM) is also a useful collaborative approach currently advocated in managing building construction projects.

- Most clients do not have sufficient knowledge of project design process specifically cost planning process. For today's nature of construction projects, it imperative that clients and their advisors are highlighted on the problems and complexities of the procedures involved in the cost planning process.

- Provide enough time for procurement. This includes adequate time for designing and cost planning to produce high quality BOQs and other tender documents. It avoids incomplete designs that result into incorrect cost estimates coupled with more guesswork.

- Adherence to effective lines of communications among project consultants is imperative towards a healthier pre-contract cost planning process. Despite the fact that emails and other advanced channels of communications dominate in the internet, technical design and coordination meetings should not be under rated. It is worth noting that after every design stage a feedback analysis of the design success would act as a shock absorber to cost implications of design variables.

- Improve existing cost information systems and cost data banks to be reliable and up to date. Nevertheless, centralised data sources could be tested if workable. Up-country regional cost data sources for each particular location may also be tested. This is because of differing logistics in terms of material availability and transportation.

- Increase transparency among project team members.

- Minimise provisional sums in BOQs by replacing them with actual measurement. This may help reduce guesswork in pricing renders.

- Preparation and dissemination of cost planning procedures/ guidelines/ documents.

- Use of computer construction software for estimating, tendering, valuation and cost analysis.

\section{References}

i. AQRB Directory (2016). List of registered architects, quantity surveyors, architecturaland quantity surveying assistants, architectural technicians, architectural draughtsmen and practicing firms. Dar es Salaam. Retrieved: May, 2016, from http:/ / www.aqrb.go.tz

ii. Association of Project Management (2006). Project Management Body of Knowledge:PMBOK Guide. 5thedn., High Wycombe: APM Publishing.

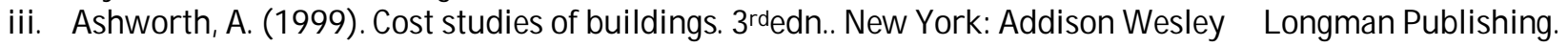

iv. Ashworth, A. (2004). Cost studies of buildings. $4^{\text {th }}$ edn., New York: Addison Wesley Longman Publishing.

v. Ashworth, A. (1982). Construction economics. New York: Addison Wesley Longman Publishing.

vi. Ashworth, A. \& Hogg, K. (2007). Willis's practice and procedure for the quantitysurveyor.12thedn., Oxford: Blackwell Publishing.

vii. Barton, B. (1985). The quantity surveyor in service to the nation for economic recovery: the forgotten role of the quantity surveyor in economic development planning and budgeting. A paper presented on the 10 th anniversary of the founding of the Ardhi Institute - Dar es Salaam 19 November 1985 (Now Ardhi University).

viii. Cong, J., Mbachu, J. and Domingo, N. (2014). Factors influencing the accuracy of pre- contract stage estimation of final contract price in New Zealand. International Journal of Construction Supply Chain Management Vol. 4, No. 2 (pp. 51-64). DOI: 10.14424/ ijcscm402014-51-64

ix. CoST Tanzania (2010). 'Bundles of documents for disclosure'. Construction Sector Transparency Initiative (CoST, Tanzania). October, 2010.

x. Edmeades, D. H. (1973). Building economics and measurement (metric), Part II.Construction management series, 1stedn., London: The Estate Gazette Ltd.

xi. Emuze, F. (2017). A Discourse on Lean Construction in Africa, Using a Supply Chain Example. Journal of Construction Project Management and Innovation, Vol. $7 \quad$ (1); $\quad$ pp 1664 - 1674.

xii. ERB Directory (2016). List of registered engineers, graduate engineers and practicing firms.Available; http:/ / www.erb.go.tz, retrieved: September 30, 2016.

xiii. Ernest, K., Theophilus, A-K. and Edward, B. (2017). 'Exploring cost planning practices by Ghanaian construction professionals'., Int. J. Project Organisation and Management, Vol. 9, No. 1, pp.83-93.

xiv. Ferry, D. \& Brandon, P. (1991). Cost planning of buildings. 6thedn., Oxford: BSP Professional Books.

xv. Florence Y.Y. Ling \& Paul H.K. Ho (2013). Special Issue on Project Cost and Contract Management, International Journal of Project Organisation and Management, 5(1/2): 1-3; Editorial, January 2013

xvi. Gleason, L. (2003). Cost planning. Project Kaleidoscope, Drury University, 2003.

xvii. Hadavi, H. (2007). 'Cost engineering and control', Spring Quarter, 2007; Civil $\quad$ Engineering 435, USA.

xviii. Kamala, A. \& Hayilakwahhi, J. (1997). Measures for effective participation in work opportunities: Workshop on future prospects of the quantity surveying profession in Tanzania. NCC, PPF House conference room, Dar es Salaam, 20th November, 1997. 
xix. Kesogukewele, M. (1998). Managing construction industry development, the case for Tanzani. NCC conference proceedings. Report on the $1^{\text {st }}$ meeting of the CIB Task Group 29 (TG29), at Arusha conference centre, Tanzania. 21-23 September, 1998.

xx. Kirkham, R. (2007). Ferry \& Brandon's cost planning of buildings. 8thedn., UK;

xxi. Kombo, D. K. \& Tromp, D. L. (2006). Proposal and thesis writing: an introduction,

Blackwell Publishing.

Nairobi: Paulines publications Africa.

xxii. Kothari, C.R. (2004). Research Methodology. 2ndedn., Jaipur, India: New Age International Publishers.

xxiii. Kwakye, A. A. (1997). Construction project administration in practice. England: Pearson Education Limited.

xxiv. Luvara, V. G. (2009). Towards value management in building projects of Tanzania. Unpublished master's dissertation, Dar es Salaam: Ardhi University.

xxv. Mamiro, G. J. \& Kasuwi, O.A. (2005). Management of public funded construction projects.CI Forum 2005 proceedings, at Karimjee Hall, Dar es Salaam, 25-27 August, 2005.

xxvi. Marcel Frei; Jasper Mbachu; Robyn Phipps (2013). Critical success factors, opportunities and threats of the cost management profession: the case of Australasian quantity surveying firms, International Journal of Project Organisation and Management, 5(1/2): pp. 4 - 24.

xxvii. Mugenda, O. M., \& Mugenda, A.G. (1999). Research methods: quantitative \& qualitativeapproaches. Nairobi: Acts Press.

xxviii. Mushumbusi, M. Z. (1997). Education and training for quantity surveyors in Tanzania: Workshop on future prospects of the quantity surveying profession in Tanzania. NCC, PPF House conference room, Dar es Salaam, 20th November, 1997.

xxix. Mushumbusi, M. Z. (2005). The impact of globalization in quantity surveying services in Tanzania (trends, procurements, formation of East African Union \& business challenges). The 8th CPD seminar, at New Africa Hotel, Dar es Salaam, 1 ${ }^{\text {st }}$ April, 2005.

xxx. Mushumbusi, M. Z. (2010). Survival of the quantity surveying profession in Tanzania.The 13 ${ }^{\text {th }}$ CPD seminar, at St. Gasper's Conference, Dodoma, 19th March, 1997.

xxxi. Mutabuzi, D. (2007). The role of a quantity surveyor in management practices of building projects in Tanzania. The 9th CPD seminar on 'management of construction projects in Tanzania', proceedings at Karimjee Hall, Dar es Salaam, $14^{\text {th }} \quad$ September, 2007.

xxxii. Naoum, G. (1998). Dissertation research and writing for construction students. Linacre House, Jordan Hill, Oxford: Elsevier Butterworth-Heinemann.

xxxiii. Nachmias, C. and Nachmias, D. (1996). Research methods in social sciences. $5^{\text {thedn., }}$ Arnold.

xxxiv. Nicolao, S. (2010). Areas of attention for building economists. TIQS Newsletter, TanzaniaInstitute of Quantity Surveyors, Issue 11, August - October, 2010.

xxxv. Ndihokubwayo, R. and Haupt, T. (2008). Outcomes of the occurrence of variation orders - construction industry stakeholders' views. Association of Schools of Construction of Southern Africa, PO Box 1906, Bellville, 7735, South Africa; $\quad$ Third Built Environment Conference in Cape Town South Africa, July 62008.

xxxvi. Oyegoke, A. S. (2006). Managing clients' expectations in project delivery- A Comparative Study of Delivery System. NIQS 22nd Bienniel Conference in $\quad$ Calabar Nigeria 22nd - 25th November 2006.

xxxvii. Pierre MacDonald Oosthuizen; Frank Herman Berry (2013). Five maturity pillars of a quantity surveying company, International Journal of Project Organisation and $\quad$ Management (IJPOM). Vol. 5, No. 1/ 2, pp.25 - 47

xxxviii. Potts, K. F. (1994). Major construction works: contractual and financial management,Birmingham: Brendan Patchell.

xxxix. Price, A. D., Edum-fotwe, F. T. \& Lema, N. M. (1998). Benchmarking construction project performance. NCC conference proceedings; Report on the 1st meeting of the CIB Task Group 29 (TG29), at Arusha conference centre, Tanzania, 21-23 September, 1998.

xl. Project Management Institute (2000). A Guide to the Project Management Body of Knowledge: PMBOK Guide. Available: http:/ / www.pmi.org/ , retrieved: 4th February, 2011 from

xli. Project Management Institute Inc. (2004). A Guide to the Project Management Body of Knowledge: PMBOK Guide. 3rd edn., Newtown Square, USA.

xlii. Ramabodu, M. S. \& Verster, J. P. (2010). Factors attributing to cost overruns in construction projects. Proceedings; The 5thBuilt Environment Conference, Durban, South Africa, 18-20 July, 2010

xliii. Ramabodu, M. S. \& Verster, J. P. (2013). Factors that influence cost overruns in South African public sector mega-projects. International Journal of Project $\quad$ Organisation and Management, 5(1/2): 48 - 56 · January 2013. DOI: 10.1504/ IJPOM.2013.053153

xliv. Ramus, J.W. (1989). Contract practice for quantity surveyors. 2ndedn., Oxford: $\quad$ Heinemann Ltd.

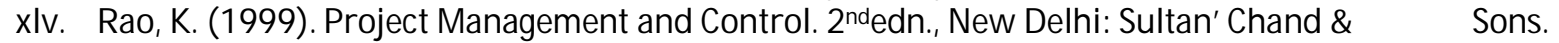

xlvi. RICS Books (2003). The surveyors' construction handbook. Coventry, UK: RICS Business Services Ltd.

xlvii. Rwelamila, P. D. (2007). Project management in the Tanzanian construction industry (addressing the knowledge base question). The $9^{\text {th }} \mathrm{CPD}$ seminar on 'management of construction projects in Tanzania', proceedings at Karimjee Hall, Dar es $\quad$ Salaam, 14th September, 2007. 
xlviii. Samizi, M. (2008). Towards improvement of cost management practices in construction projects. Unpublished master's dissertation, Dar es Salaam: University of Dar es Salaam.

xlix. Seeley, I. H. (1976). Building Economics. 3 $3^{\text {rd }}$ edn., London: Macmillan Press Ltd.

1. Seeley, I. H. (1996), Building economics: Appraisal and control of building design cost and efficiency. $4^{\text {th }}$ edn., London: Macmillan press ltd.

li. State Government of Victoria, Australia, Department of Health; Capital Development Guidelines - Cost planning. Available: www.capital.dhs.vic.gov.au/ capdev/ Planning Evaluation/ Cost Planning, retrieved: 29th December, 2010.

lii. Tango, J. T. (2004), Cost management and control, Architects and Quantity Surveyors' Newsletter; Issue No. AQ0401, April - June, 2004 